\title{
Kekerasan Anak dalam Keluarga
}

\author{
Abdul Kadir ${ }^{1}$, Anik Handayaningsih ${ }^{2}$ \\ Magister Psikologi, Universitas Muhammadiyah Surakarta \\ kadirsahlan781@gmail.com¹, handayaningsihanik@yahoo.com²
}

\begin{abstract}
The family has a significant role and function to the developmet and future of children. A child must get the widest opportunity to be able to grow and develop optimally both physically, psychologically, socially, and spiritually. Children also need to get their rights to be protected and prospered. All forms of violence against children need to be prevented and overcome, especially physical violence against children. Domestic violence is an activity in which the perpetrator (who is a member of the household) attacks someone who is also a member of the household. Violence against children means violence committed by parents against their children. Parental awareness about of violent punishment is still low, this is still low, this is influenced by many factors as lack of knowledge about violence, the existence of a tradition of violence, to psychological problems. But in general parents feel that violence is the only solution to nurture and educate children. The purpose of this study was to determine the form of physical violence against children carried out by parents. This research uses a literature review with data obtained from journals, books and the internet. The results of this article include the inheritance of intergenerational violence, violence against children in the family difficult to be revealed in the public sphere, and cultural background (The presence of relationships in society that always puts children in the lowest position.
\end{abstract}

Keywords : parents, children, violence, family

\begin{abstract}
Abstrak
Keluarga memiliki peran dan fungsi yang cukup besar terhadap perkembangan dan masa depan anak. Seorang anak harus mendapatkan kesempatan yang seluas-luasnya untuk dapat tumbuh dan berkembang secara optimal baik fisik, psikis, sosial, maupun spiritual. Anak juga perlu mendapatkan hak-haknya untuk dilindungi dan disejahterakan serta Segala bentuk tindak kekerasan terhadap anak perlu dicegah dan diatasi khususnya kekerasan fisik terhadap anak. Kekerasan dalam rumah tangga merupakan aktifitas di mana pelaku (yang merupakan anggota rumah tangga) menyerang seseorang yang juga merupakan anggota dari rumah tangga tersebut. Kekerasan terhadap anak berarti kekerasan yang dilakukan oleh orang tua terhadap anaknya. Kesadaran orang tua mengenai dampak buruk dari hukuman kekerasan masihlah rendah, hal ini dipengaruhi adanya banyak faktor seperti kurangya pengetahuan mengenai kekerasan, adanya tradisi kekerasan, hingga masalah psikologis. Namun pada umumnya orang tua merasa bahwa kekerasan merupakan satu-satunya solusi untuk mengasuh dan mendidik anak. Tujuan penelitian adalah untuk mengetahui bentuk kekersan fisik terhadap anak yang dilakukan oleh orangtua. Peneltian ini menggunakan Kajian literatur dengan data yang diperoleh dari jurnal, buku, dan internet. Hasil dari dari artikel ini meliputi dari pewarisan kekerasan antar generasi, kekerasan terhadap anak dalam keluarga sulit terungkap di ruang publik, dan latar belakang budaya (Adanya hubungan kedudukukan dalam masyarakat yang selalu menempatkan anak dalam posisi terbawah).
\end{abstract}

Kata Kunci : Orang tua, Anak, Kekerasan, Keluarga 


\section{Pendahuluan}

Keluarga merupakan tempat pertama dan utama bagi anak untuk mendapatkan pembinaan mental dan pembentukan kepribadian. Fungsi dan peran keluarga memiliki andil yang sangat signifikan dalam perkembangan dan masa depan anak, sehingga membentuk genersi yang berkualitan untuk masa depan anak sendiri. Namun pada kenyataannya sering dijumpai di masyarakat, anak yang seharusnya mendapatkan perlindungan di dalam keluarga, justru mendapakan perilaku kekerasan pada anak baik fisik maupun psikis.

Empat puluh enam kasus kekerasan anak di dalam keluarga terjadi di Bone, Sulawesi selatan dalam tiga tahun terakhir. Data tersebut berdasarkan Laporan Polisi (LP) masuk ke Polres bone selama tiga tahun terakhir, 2016 - 2018 menyampaikan kekerasan terhadap anak dilakukan orang tua pelaku delapan belas orang dan pelaku lain dua puluh delapan orang (Tribun, 2018)

Polisi meringkus pelaku kekerasan terhadap bocah berusia delapan tahun berinial B di Kuningan, Jawa Barat. Sang bocah diketahui korban kekerasan dari tiga orang berbeda, yang satu diantaranya adalah ibu kandung sendiri. Kepala Bidang Humas Polda Metro Jaya mengatakan terungkapnya kasus tersebut bermula dari viralnya video berdurasi lebih dari dua menit di dunia maya. Dalam video itu terpapar seorang anak laki-laki mengalami berbagai luka fisik pada sekujur tubuhnya lantaran penganiayaan. Video itu diambil sekitar 16 Januari 2018 oleh guru B saat masih di sekolah (CNN, 2018)

Komisi perindungan anak (KPAI) menyatakan bahwa kekerasan pada anak selalu meningkat setiap tahun. Hasil pemantau kpai dari 2011 sampai 2014 , terjadi peningkatan yang signifikan " tahun 2011 terjadi 2178 kasus kekerasan, 2012 ada 3512 kasus, 2013 ada 4311 kasus, 2014 ada 5066 kasus. Wakil ketua KPAI, Maria advianti mengatakan bahwa anak bisa menjadi korban atau pelaku kekerasan dengan lokasi kasus kekerasan pada anak ada 3, yaitu di lingkungan keluarga, lingkungan sekolah, dan di lingkungan masyarakat. Hasil monitoring dan evaluasi KPAI tahun 2012 di 9 provinsi menunjukkan bahwa 91\% anak menjadi korban di lingkungan keluarga, 87,6\% di lingkungan sekolah dan 17,9\% di lingkungan masyarakat (KPAI, 2015)

Di Poli Psikologi RSJD Klaten mendapatkan rujukan beberapa kasus gangguan psikologis anak. Setelah dirunut ke belakang, anak mengalami gangguan psikologis disebabkan oleh perilaku kekerasan dari orang tua. Dalam 1 bulan terakhir Poli Psikologi mendapatkan 3 rujukan kasus gangguan psikologis anak dari suatu desa Tambakan. Desa ini terdiri dari 17 dukuh dengan jumlah penduduk 4.402, mayoritas penduduk bekerja sebagai petani dan buruh dengan tingkat pendidikan masyarakat mayoritas SD dan SMP. Menurut informasi dari Kepala Desa, perilaku kekerasan pada anak yang dilakukan oleh orangtua banyak terjadi di desa Tambakan ini dan dianggap sebagai sesuatu hal yang biasa dan wajar. Hal tersebut juga nampak 
dalam pengamatan peneliti dimana lebih dari 8 keluarga melakukan kekerasan pada anak. Bentuk kekerasan yang dilakukan adalah kekerasan fisik, antara lain memukul anak dengan sapu, menampar, mencubit. Kekerasan dilakukan cukup sering, bahkan ada satu keluarga yang melakukan hal tersebut hampir setiap hari (Rina \& Rini , 2015)

Studi menunjukkan bahwa lebih kurang 30\% anak-anak yang diperlakukan dengan kekerasan menjadi orang tua yang bertindak keras kepada anak-anaknya. Sementara itu, hanya 2 sampai 3 persen dari semua individu menjadi orang tua yang memperlakukan kekerasan kepada anak-anaknya. Anak-anak yang mengalami perlakuan salah dan kekerasan mungkin menerima perilaku ini sebagai model perilaku mereka sendiri sebagai orang tua. Tetapi, sebagian besar anak anak yang diperlakukan dengan kekerasan tidak menjadi orang dewasa yang memperlakukan kekerasan kepada anak-anaknya (Pumama , 2013 ).

Perilaku keji orangtua sering luput dari pengamatan, tak terkecuali di Amerika Serikat, yang menjunjung tinggi hak asasi manusia. Selama periode 1985-1992 angka perlakuan keji pada anak justru memperlihat peningkatan sampai 50\%. Di amerika Serikat, setiap tahun 1\% di antaranya meninggal dunia. Angka yang sebenarnya tentu lebih tinggi, sekitar 2000 orang di antaranya meninggal dunia, di samping tidak semua kasus dilaporkan di Amerika Serikat, pada tahun 1993 dilaporkan sekitar 3 juta kasus perlakuan keji terhadap anak di bawah umur 18 tahun dan 1299 anak di antaranya meninggal dunia. Di Indonesia, pada tahun 1992 dilaporkan sekitar 4,87\% kasus cedera pada anak yang dirawat di rumah sakit merupakan kasus perlakuan keji yang dilakukan oleh orangtua (Medika, 2001)

Munculnya kekerasan pada anak dalam rumah tangga sering terjadi, antara lain kekerasan yang melibatkan pihak ayah, ibu dan saudara yang lainnya. Selain itu kekerasan juga timbul karena tekanan ekonomi karena ketidakmampuan keluarga untuk memenuhi kebutuhan anggota keluarganya. Sebagai orang tua, pendidikan yang utama dan pertama memegang peranan yang paling penting, agar anak tidak terpengaruh pada lingkungan yang tidak baik yang dapat memicu anak tersebut untuk melakukan tindakan kekersan. (Siti, 2017)

Tingkat kekerasan yang dialami oleh anak cukup tinggi. Dari beberapa jenis kekerasan, kekerasan emosional, kekerasan ekonomi, dan kekerasan fisik lebih banyak dilakukan. Di samping itu, orang tua juga pernah melakukan kekerasan verbal dan kekerasan sekual Rendahnya pendidikan dan perhatian orang tua serta minimnya pengetahuan cara mendidik anak yang benar, akan berdampak terhadap perilaku orang tua dalam memberikan pengasuhan kepada anak. Seperti yang ditunjukkan dalam penelitian ini, pendidikan formal yang dikuti orang tua sebagian besar juga tergolong rendah yaitu pendidikan sekolah pertama, ditambah lagi orang tua yang kurang mengikuti berbagai program parenting, sehingga banyak kesalahan yang dilakukan dalam mendidik dan mengasuh anak, anak menjadi beban orang tua yang tidak pernah berakhir. 
Dalam penelitian ini ditemukan bahwa sebagian besar orang tua sering melakukan kekerasan fisik pada anak secara spontan dan dengan volume yang sering. Sebagian besar keluarga tidak memahami bahwa anak harus mendapat pengasuhan tanpa kekerasan. Fenomena kekerasan di keluarga seakan lumrah, biasa dan dibenarkan oleh kultur. Anak menjatuhkan makanan, anak merengek minta mainan, anak lari-larian dan hal-hal kecil yang dilakukan kerapkali memicu orang tua marah dan melakukan kekerasan secara fisik. Bentakan dan pukulan sering dialamatkan kepada anak dengan berlindung pada dalih agar anak disiplin dan tidak manja.

Sedangkan penelitian dari (Pumama , 2013 ) kekerasan terhadap anak menjadi salah satu persoalan yang memprihatinkan bagi bangsa ini. Apalagi jika hal itu terjadi dalam keluarga, yang seharusnya menjadi tempat bernaung yang paling aman bagi anak-anak. Ironisnya, pelaku kekerasan tersebut adalah orang-orang yang dekat dengan anak, bahkan tak jarang adalah orang tua mereka sendiri. Banyak faktor yang menjadi pemicunya; kekerasan yang diwariskan, stress sosial, isolasi sosial dan juga struktur keluarga. Padahal sudah jelas, hukum nasional, internasional dan juga hukum islam memberikan perlindungan yang tegas terhadap hak-hak anak, dan kekerasan menjadi satu hal yang di- kecam. Pendidikan anak yang humanis, pemberian kasih sayang yang tulus dan ucapan yang lemah lembut jauh dari nuansa kasar dank keras merupakan awal bagaimana me- nanamkan kelembutan dan kasih sayang pada anak dan menjauhkan mereka dari segala tindak kekasaran dan ke- kerasan.

\section{Metode Penelitian}

Penelitian ini mengunakan pendekatan kajian literatur dengan mencari referensi teori yang relevan dengan kasus atau permasalahan yang ditemukan. Referensi teori yang diperoleh dengan jalan penelitian kajian literatur. Sedangkan metode pengumpulan data menggunakan data yang diperoleh dari jurnal, buku, dan internet. Sedangkan metode analisis data menggunakan analisis deskriptif. Dengan cara mendeskripsikan fakta-fakta yang kemudian disusul dengan analisis, tidak semata-mata menguraikan, melainkan juga memberikan pemahaman dan penjelasan. Sedangkan penelitian ini memfokuskan pada kekerasan fisik terhadap anak.

\section{Hasil dan Pembahasan}

\section{a. Pengertian Kekerasan terhadap Anak}

Abuse adalah kata yang biasa diterjemahkan menjadi kekerasan, penganiayaan, penyiksaan, atau perlakuan salah. Dalam The Social work dictionary, (Barker, 1978) mendefinisikan abuse sebagai "impropert behavior intended to cause physical, psychological, or financial harm to an individual or group" (Kekersan adalah perilaku tidak layak yang 
mengakibatkan kerugian atau bahaya secara fisik, psikologis, atau finansial, baik yang dialami individual maupun kelompok). Sedangkan istilah child abuse atau kadang-kadang child maltreatment adalah istilah yang bisa digunakan untuk menyebut kekersan terhadap anak.

Kekerasan terhdap anak adalah perbuatan disengaja yang menimbulkan kerugian atau bahaya terhadap anak-anak secara fisik maupun emosional. Istilah child abuse meliputi berbagai bentuk tingkah laku, dari tindakan ancaman fisik secara langsung oleh orangtua atau orang dewasa lainnya sampai kepada penelantaran kebutuhan-kebutuhan dasar anak.

Sementara itu (Barker, 1978) kekerasan terhadap anak adalah tindakan melukai yang berulang-ulang secara fisik dan emosional terhdap anak yang ketergantungan, melalui desakan hasrat, hukuman badan yang tak terkendali, degradasi dan semoohan permanen atau kekersan seksual, biasanya dilakukan para orangtua atau pihak lain yang seharusnya merawat anak.

\section{b. Bentuk-Bentuk Kekerasan Terhadap Anak}

Terry E. Lawson, Psikiater anak yang dikutip (Rakhmat, 1999) mengklasifikasikan kekerasan terhadap anak (child abuse) menjadi empat bentuk, yaitu: emotional abuse, verbal abuse, physical abuse, dan sexual abuse. Sementara itu, menurut (Suharto, 1997 ) mengkelompokkan child abuse menjadi: physical abuse (kekerasan secara fisik), psychology abuse (kekerasan secara psikologis), sexual abuse (kekerasan secara seksual) dan sosial abuse (kekerasan secara sosial). Keempat bentuk child abuse ini dapat dijelaskan sebagai berikut:

- Kekerasan anak secara fisik, yaitu penyiksaan, pemukulan, dan penganiayaan terhadap anak, atau menggunakan benda-benda tertentu, yang menimbulkan luka-luka fisik atau kematian pada anak. Bentuk luka dapat berupa lecet atau memar kematian pada anak. Bentuk luka dapat berupa lecet atau memar akibat persentuhan atau kekerasan benda tumpul seperti bekas, gigitan, cubitan, ikat pinggang atau rotan. Dapat pula berupa luka bakar akibat bensin panas atau berrpola akibat sundutan rokok atau setrika. Lokai luka biasanya ditemukan pada daerah paha, lengan, mulut, pipi, dada, perut, punggung atau daerah bokong. Terjadinya kekerasan terhadap anak secara fisik umumnya dipicu oleh tingkah laku anak yang tidak disukai orangtuanya, seperti oleh tingkah laku anak yang tidak disukai orangtuannya, seperti anak nakal atau rewel, minta jajan, buang air kencing atau muntah di sembarangan tempat, memecahkan barang berhargga.

- Kekerasan anak secara psikis, meliputi penghardikan, penyampaian kata-kata kasar dan kotor, memperlihatkan buku, gambar, dan film pornografi pada anak. Anak yang 
mendapatkan perlakuan ini umumnya menujukkan gejala perilaku maladaftif, seperti menarik diri, pemalu, menagis jika didekati, takut ke luar rumah dan takut bertemu dengan orang lain.

- Kekerasan anak secara sosial, dapat mencakup pelantaran anak dan ekspolitasi anak. Penelantaran anak adalah sikap dan perlakuan orangtua yang tidak memberikan perhatian yang tidak memberikan perhatian yang layak terhadap proses tumbuhkembang anak.

- Kekerasan anak secara seksual, dapat berupa perlakuan prakontak seksual antara anak dengan anak dengan orang yang lebih besar (melalui kata, sentuhan, gambavisual, maupun perlakuan kontak seksual secara langsung antara dengan orang dewasa (insert, perkosaan, eksploitasi seksual).

Terjadinya kekersan terhadap anak di sebabkan berbagai faktor yang mempengaruhi. Faktor-faktor yang mempengaruhinya demikian kompleks seperti yang di jelaskan (Rusmil, 2004) menjelaskan bahwa penyebab atau resiko terjadinya kekerasan dan penelantaran terhadap anak di bagi kedalam tiga bagian: factor orangtua, keluarga, faktor lingkungan sosial/komunitas, dan fakor anak sendiri: (1) Faktor orangtua/keluarga : Faktor orangtua memegang peranan penting terjadinya kekersan dan penelantaran pada anak. Factor-faktor yang menyebabkan orangtua melakukan kekerasan pada anak: (a) praktik-praktik budaya yang merugikan anak: kepatuhan anak kepada orangtua, hubungan asimetris. (b) dibesarkan dalam penganaiayaan.(c) ganguan mental. (d) belum mencapai kematangan fisik, emosi maupun sosial terutama mereka yang mempunyai anak sebelum berusia 20 tahun. (e) pecandu minuman keras dan obat. (2) Faktor lingkungan sosial/komunitas: Kondisi lingkun: gan sosial juga dapat menjadi pencetus terjadinya kekersan pada anak. (3) Factor lingkungan sosial yang dapat menyebabkan kekersan pada ank. Factor lingkungan sosial yang dapat menyebabkan kekersan dan penelantaran pada anak di antaranya: (a) kemiskinan dalam masyarakat dan tekanan nilai rialistis. (b) kondisi sosial-ekonomi yang rendah. (c) adanya nilai masyarakat bahwa anak adalah milik orangtua sendiri. (d) status wanita yang dipandang rendah. (e) sistem keluarga patriarkal. (f) nilai masyarakat yang terlalu individualisistis. (3) faktor anak itu sendiri (a) penderita gangguan perkembangan, menderita penyakit kronis disebabkan ketergantungan anak kepada lingkungannya. (b) perilaku menyimpang pada anak.

Menganiaya anak mempunyai karakteristik tertentu, seperti : mempunyai latar belakang (masa kecil) yang juga penuh kekersan, ia juga sudah terbiasa menerima pukulan ;ada pula yang menganggap anak sebagai individu yang seharusnya memberikan dukungan dan perhatian kepada orangtua (role model) sehinga ketika anak tidak dapat memenuhi 
harapan tersebut, orangtua mersa bahwa anak harus di hukum ; karakter lainnya adalah ketidaktahuan kebutuhan perkembangan anak, misalnya usia anak belum memungkinkan untuk melakukan sesuatu tetapi karena sempitnua pengetahuan orangtua, si anak dipaksa untuk melakukannya dan ketika ternyata anak memang belum mampu, orangtua menjadi marah.

Banyak anak belajar perilaku kekerasan dari orangtuanya dan ketika tumbuh menjadi dewasa mereka melakukn tindakan kekerasan kepada anaknya (Abu, 2018). Perilaku kekerasan diwarisi (transmitted) dari generasi ke generasi. Studi-studi menujukkan bahwa lebih kurang 30\% anak-anak yang diperlakukan dengan kekerasan menjadi orangtua yang bertindak keras kepada anak-anaknya. Sementara itu, hanya 2 sampai 3 persen dari semua individu menjadi orangtua yang memperlakukan kekerasan kepada anak-anaknya. Anak-anak yang mengalami perlakuan salah dan kekerasan mungkin menerima perilaku ini sebagai model perilaku mereka sendiri sebagai orangtua. Tetapi, sebagian besar anak-anak yang diperlakukan dengan kekerasan tidak menjadi orang dewasa yang memperlakukan kekerasan kepada anak-anaknya. Beberapa ahli yakin bahwa peramal tentang tindakan-tindakan kekerasan di masa depan adalah anak menyadari bahwa perilaku tersebut salah. Anak yang yakin bahwa perilaku buruk dan layak mendapatkan tindakan kekerasan akan lebih sering menjadi orangtua yang memperlakukan anaknya secara salah, dibandingkan anak-anak yang yakin bahwa orangtua mereka salah untuk memperlakukan mereka dengan tidakan kekerasan.

Struktur Keluarga: tipe-tipe keluarga tertentu memiliki risiko yang meningkat untuk melakukan tindakan kekersan dan pengabaian kepada anak. Misalnya orangtua, tunggal lebih memungkinkan melakukan tindakan kekersan terhadap anak dibandingkan dengan orangtua utuh. Karena, keluarga dengan orangtua tunggal biasanya berpendapatan lebih kecil dibandinkan keluarga lain, sehingga hal tersebut dapat dikatakan sebagai penyebab meningkatnya tindakan kekerasan terhadap anak.

Keluarga-keluarga yang sering bermasalah mempunyai tingkat tindakan kekerasan terhadap yang lebih tinggi dibandingkan dengan keluarga-keluarga yang tanpa masalah. Selain itu, keluarga-keluarga di mana baik suami atau istri mendominasi di dalam membuat keoutusan penting, seperti: di mana bertempat tinggal, pekerjaan apa yang mau di ambil, bilamana mempunyai anak, dan berapa banyak uang yang dibelanjakan untuk makan dan perumahan mempunyai tingkat kekerasan terhadap anak yang lebih tinggi dibandingkan dengan keluarga-keluarga yang suami-istri sama-sama bertanggung jawab atas keputusankeputusan tersebut (Abu, 2018) 


\section{WACANA}

\section{c. Efek Kekerasan Terhadap Anak}

Menurut YKAI (Yayasan Kesejahteraan Anak Indonesia) menyimpulkan bahwa kekerasan dapat menyebabkan anak kehilangan hal-hal yang paling mendasar dalam kehidupannya dan pada gilirannya berdampak sangat serius pada kehidupan anak di kemudian hari, antara lain: (1) cacat tubuh permanen. (2) kegagalan belajar. (3) gangguan emosional bahkan dapat menjurus pada gangguan kepribadian. (4) konsep diri yang buruk dan ketidakmampuan untuk mempercayai atau mencintai orang lain. (5) pasif dan menarik diri dari lingkungan, takut membina hubungan baru dengan orang lain. (6) Agresif dan kadang-kadang melakukan tindakan kriminal. (7) menjadi penganiayaan ketika dewasa. (menggunakan obat-obatan atau alcohol. (9) kematian) (Gelles, 2004)

Gambaran yang lebih jelas tentang efek tindakan kekerasan pda anak juga bias dilihat dalam penhelasan Moore dalam (Nugroho, 1992) yang mengamati beberapa kasus anak yang yang menjadi korban penganiayaan fisik. Diungkapkannya bahwa efek tindakan kekerasan tersebut demikian luas dan secara umum dapat diklasifikasikan dalam beberapa kateogori. Ada yang menjadi negative dan agresif serta mudah frustrasi; ada yang menjadi sangat pasif dan adapis; ada yang tidak mempunyai kepribadian sendiri, apa yang dilakukan sepanjang hidupnya hanyalah memenuhi keinginan orangtuannya (parental extension), mereka tidak mampu mengharggai dirinya endiri (chronically low self-esteem): ada pula yang sulit menjadi relasi dengan individu dengan individu lain: dan yang tampaknya paling parah adalah timbulnya ras benci yang luar biaa terhadap dirinya (selfhalte) karena merasa hanya dirinyalah yang selalu bersalah sehingga menyebabkan penyiksaan terhadap dirinya, dan rasa benci terhadap dirinya sendiri ini menimbulkan tindakan untuk menyakiti diri sendiri, termasuk bunuh diri dan sebagainya. Selain akibat psikologis tersebut, Moore juga menemukan adanya kerusakan fisik, seperti perkembangan tubuh yang kurang normal, juga rusaknya system saraf, dan sebagainya.

Dari uraian di atas terlihat bahwa dampak dari tindakan kekerasan terhadap anak begitu mengenaskan. Mungkin belum banyak orang yang menyadari bahwa pemukulan yang bersifat fisik itu bisa menyebabkan kerusakan emosional anak. Berkaitan dengan hal tersebut, Hofeller dan La Rossa dalam (Nugroho G. , 2003) menjelaskan tentang efek kekerasan terhadap psikologis anak. Diungkapkan bahwa anak-anak yang masih kecil sering susah tidur dan bangun di tengah malam menjerit ketakutan. Ketika mereka semakin besar, anak laki-laki cenderung menjadi sangat agresif dan bermusuhan dengan orang lain; sementra anak perempuan sering mengalami kemunduran dan menarik diri ke dalam dunia fantasinya sendiri. Namun dampak yang paling menyedihkan adalah anak perempuan kemudian merasa semua anak pria itu menyakiti (dan menyebabkan beberapa di antaranya membenci pria), sedangkan anak laki-laki kemudian percaya bahwa laki-laki 
mempunyai hak untuk memukul istrinya. Seorang wanita bercerita bahwa ia akhirnya memutuskan untuk meninggalkan suaminya ketika melihat anak laki-lakinya yang berusia 8 tahun menganiaya adik perempuannya; "hal itu sungguh membuatku marah. Saya pegang dia dan saya Tanya apakah dia mengetahui apa yang sedang dilakukannya.ia melihat ke mata saya dan berkata, "jika ayah dapat melakukannya, demikian juga saya”.

Anak-anak memang selalu peka. Sering orangtua tidak menyadari bahwa apa yang terjadi di antara mereka begitu memengaruhi anak. Seiring dikatakan, anak merupakan cermin dari apa yang terjadi dalam suatu rumah tangga. Jika suasana keluarga sehat dan bahagia, maka wajah anak begitu ceria dan berisi. Sebaliknya jika mereka murung dan sedih, biasanya telah terjadi sesuatu yang berkaitan dengan orangtuannya. Sebagai wadah sosialisasi primer, di mana anak belajar untuk pertama kalinya mengenal nilai-nilai dan cara bertingkah laku, perilaku orangtua sering memengaruhi perilaku anak-anaknya kelak. Jika kekersan begitu dominan, tidaklah mengherankan jika anak-anak kemudian melakukannya dan bahkan terbawa sampai dewasa. Karena kekerasan begitu sering terjadi dalam keluargannya, maka menganggap hal itu sebagai hal yang "normal" dan sudah seharusnya.

Kita sering menjumpai banyak hal kejadian dan bentuk kekerasan yang di alami anak di dalam lingkup keluarga atau orangtua sendiri. Diantaranya bentuk kekerasan yang dialami ialah sebagai berikut:

Kekerasan Psikologis//Emosional, kekerasan yang dialami anak juga bisa berupa fisik dan seksual. Menurut The National Association Of Social Workers, kekersan dalam keluarga mrupakan siksaan emosional, fisik dan atau seksual yang dilakukan secara sadar, sengaja, atau kasar dan diarahkan kepada anggota keluarga atau rumah tangga (Soetarso, 2004). Dalam lingkup yang lebih luas, juga meliputi dijelaskan dalam bentuk penelantaran (neglect), Sebagaimana dijelaskan Undang-Undang RI Nomor 23 Tahun 2004 Tentang Penghapusan Kekerasan Dalam Rumah Tangga. Dalam undang-undang ini yang dimaksud dengan kekerasan dalam rumah tangga adalah setiap perbuatan terhadap perbuatan seseorang terutama perempuan, yang berakibat timbulnya kesengsaraaan atau penderitaan secara fisik, seksual, psikologis atau penelantaran rumah tangga termasuk ancaman untuk melakukan perbuatan, pemaksaan, atau perampasan kemerdekaan secara melawan hukum dalam lingkup rumah tangga.

Kekerasan Emosional Atau Kekerasan Verbal, misalnya dilakukn dalam bentuk memarahi, mengomel, membentak dan memaki anak dengan cara berlebihan dan merendahkan martabat anak, termasuk mengeluarkan kata-kata yang tidak patut didengar oleh anak. Sedangkan kekerasan fisik, bisa meliputi pemukulan dengan benda tumpul 
maupun benda keras, menendang, menampar, menjewer menyundut dengan api rokok, dan menempelkan setrika pada pada tubuh, dan membenturkan kepala anak pada tembok.

\section{d. Karakteristik Kekerasan Anak dalam Keluarga}

Soetarso (2004) menjelaskan bahwa dari berbagai kepustakaan yang ada, dapat ditentukan beberapa karakteristik kekerasan dalam keluarga sebagai berikut:

Pertama, Semua bentuk kekerasan dalam keluarga menyangkut penyalahgunaan kekuatan. Pola yang umum terjadi adalah disalahgunakannya kekuatan oleh yang kuat terhadap yang lemah. Perbedaan kekuatan ini dapat berupa ukuran dan kekuatan fisik maupun status.Kedua, Adanya tingkatan kekerasan, dari yang ringan sampai sangat berat atau fatal. Ketiga, Kekerasan dilakukan berkali-kali. Kalau kendali untuk berbuat kekerasan melemah atau hilang, maka kekerasan akan terus berlangsung dan bertambah berat. Sasarannya pun bertambah meluas.Keempat, Kekerasan dalam keluarga umumnya berlangsung dalam konteks penyalahgunaan dan eksploitasi psikologis. Penghinaan verbal yang berupa ejekan atau sumpah serapah kerapkali mengawali terjadinya kekerasan fisik. Korban dibuat sedemikian rupa sehingga merasa tidak berharga, tidak berdaya, tidak dicintai, tidak penting dan lebih rendah dari manusia. Perlakuan yang tidak layak secara psikologis seperti ini dapat menganggu kemampuan korban untuk menghayati kenyataan, merendahkan citra dirinya sendiri dan menyebabkan menyalahkan dirinya sendiri. Korban tercekam oleh persaan takut, malu, marah, dan berdosa, namun kerapkali tetap loyal kepada penyiksanya. Korban mengalami konflik yang tidak dialami oleh yang dikerasi oleh orang asing atau yang tidak dikenal. Kelima, Kekerasan dalam keluarga mempunyai dampak negatif terhadap semua anggota keluarga atau rumah tangga, baik yang terlibat dalam kekerasan maupun yang tidak. Setiap orang dalam keluarga ini merasa tidak tentram. Masalah ini merupakan unsur yang sangat merusak kehidupan keluarga. Beberapa di antara konsekuensi masalah ini adalah rasa takut, saling tidak percaya, kesenjangan emosional dan fisik, hambatan komunikasi dan ketidaksepakatan.

Dari penjelasan tersebut, satu hal yang dapat digarisbawahi adalah bahwa kekerasan dalam keluarga terjadi karena penyalahgunaan kekuatan oleh yang kuat terhadap yang lemah. Orangtua yang memiliki kekuatan fisik ataupun non-fisik (karena status yang tinggi dalam struktur keluarga) atau merasa dirinya superioritas bisa berbuat apa saja, Termasuk melakukan kekerasan terhadap anak. Anak yang berada dalam posisi yang lemah dan dilemahkan tak berada menghadapi perlakuan tersebut. Seto Mulyadi (Kak Seto) merasakan keundahannya dengan mengatakan bahwa di dalam masyarakat seolah tumbuh anggapan bahwa anak adalah komunitas kelas bawah. Mereka pribadi-pribadi 
kecil dan lemah yang sepenuhnya berada di bawah kendali kekuasaan orang dewasa. Orangtua pun merasa berhak melakukan apa saja terhadap anak (Abu, 2018)

Dalam konteks ini, (Soetarso, Kekersan dalam Kluarga , 2004) juga merasakan keprihatinanya dengan permasalahan anak ini. Ia mengatakan bahwa permasalahan anak sangat dramatis dan memilukan, karena dialami oleh manusia yang kemampuan fisik, mental dan solusinya masih terbatas untuk merespons berbagai resiko dan bahaya yang dihadapinya. Lebih tragis lagi dicermati bahwa dalam berbagai kasus, permasalahan tersebut justru dilakukan oleh pihak-pihak yang seyogyanya berperan mengasuh dan melindungi anak, terutama orangtua atau keluarga.

\section{e. Keluarga : Pondasi Primer Bagi Kepribadian Anak}

Pada konteks kekinian, terjadinya kekerasan terhadap anak dalam keluarga, sebagai pangkal penyebabnya adalah rapuhnya tatanan keluarga. Karakteristik tatanan keluarga yang rapuh di antaranya adalah ketidakmampuan orangtua dalam mendidik anak dengan sebaik-baiknya, yaitu tidak adanya perhatian, kelembutan dan kasih sayang dari orangtua terhadap anak. Ruang keluarga yang dihiasi oleh susunan pertengkaran, perselisihan dan permusuhan adalah sumber terjadinya kekerasan fisik dan yang paling terkena sasaran kekerasannya adalah anak.

Sejatinya kita menyadari bahwa keluarga atau rumah tangga adalah fondasi primer bagi perkembangan, kepribadian dan tingkah laku anak. Kekerasan keluarga (orangtua) dalam membentuk watak anak sangat tergantung pada subjek-subjek dalam keluarga tersebut. Orangtua, sebagai subjek terpenting dalam keluarga semestinya dapat mendidik anak dengan penuh kasih sayang dan kelembutan. Pola pendidikan yang yang diselimuti kasih sayang dan kelembutan ini akan menjadi kunci tercapainya derajat kualitas anak dikemudian hari (Abu, 2018)

Dalam hal ini, Syekh Jamaluddin Mahfuzh dalam (Abu :2018,) Mengungkapkan manfaat yang bisa didapat cara mendidik anak seperti itu : (a) Dapat menghilangkan hambatan-hambatan dan mendekatkan jarak, pemisah antara ayah dengan anak. Dengan demikian, anak merasa tidak menentukan kesulitan apa pun untuk bermusyawarah dengan ayah tentang masalah dan kehidupan yang ia hadapi. (b) Dapat melahirkan kesiapan mental anak untuk menerima nasihat dan pengarahan. (c) Dapat mengungkap kemampuan anak yang sebenarnya dan tingkat kematangan serta mentalnya. Dengan demikian, ia bisa membatasi pengarahan atau beban secara proporsional, tanpa menambahi atau menguranginya.

Tidak ada lagi alasan bagi orangtua untuk tidak membangun keluarga dengan memerhatikan dan bersahabat dengan anak-anaknya dalam "dekapan" kasih sayang dan 
kelembutan. Dalam sebuah hadits, Rasulullah Saw berpesan " Perhatikanlah anak-anakmu, dan didiklah dengan baik" (HR. Ibnu Majah) (Abu, 2018)

\section{Simpulan}

Berdasarkan hasil pembahasan di atas maka dalam ditarik kesimpulan bahwa orangtua perlu memahami kondisi anak tanpa harus tindakan kekerasan. Juga masih banyak faktor yang menyebabkan kekerasan anak terhadap anak dalam keluarga meliputi dari, pewarisan kekerasan antar generasi, kekerasan terhadap anak dalam keluarga sulit terungkap di ruang publik, dan latar belakang budaya (Adanya hubungan kedudukukan dalam masyarakat yang selalu menempatkan anak dalam posisi terbawah). Maka dari itu orantua perlu adanya kesadaran bahwa anak adalah titipan yang harus di jaga sebaik mungkin bukan untuk di aniaya apalagi sampai kepada kekerasan fisik terhadap anak. 


\section{WACANA}

\section{Daftar Pustaka}

Abu, H. (2018). Kekerasan terhadap Anak. Bandung : Penerbit Nuansa Cendekia .

Abu, H. (2018). Kekerasan Terhadap Anak. Bandung : Penerbit Nuansa Cendekia .

Barker, R. L. (1978). The social work dictionary, National Associaction of Social Workers . Maryland : Silver Spring .

CNN. (2018, Februari Senin ). Ibu kandung jadi tersangka kekerasan anak yang videonya viral . https://www.cnnindonesia.com/nasional/20180205005748-12-273775/ibu-kandungjadi-tersangka-kekerasan-anak-yang-videonya-viral.

Dinata, A. (2004, Mei 17 ). Perhatikanlah Anak-anakmu. Republika .

Gelles, R. J. (2004). child Abuse. Dalam Encyclopedia Article from Encarta. http://Encart.msn.com?enyclopedia (diakses 5 juli 204) .

KPAI. (2015, Juli Selasa ). Kekersan anak dalam keluarga . http://kpai.go.id .

Medika, M. (2001, Pebruari). Kasus kekersan anak dalam keluarga . No. 2 Tahun XXVII, .

Nugroho, F. (1992). Studi Eksploratif Mengenai Tindakan Kekerasan terhadap Anak dalam Keluarga. Jurnal Sosiologi "Masyarakat", Jakarta Sosiologi FISIP UI-Gramedia Pustaka Utama .

Nugroho, G. (2003). Anak dan Trauma Kekerasan Sosial Politik," dalam abu huraerah (Ed), Isu Kesejahteraan Sosial di tengah Ketidakpastian Indonesia. Bandun: Center for Political and Autonomy Studies, Fakultas Ilmu Sosial dan Ilmu Politik Universitas Pasundan .

Pumama , R. (2013 ). Kekersan terhadap Anak di dalam Rumah Tangga Perspektif Hukum Islam . Journal SAWWA, ISBN Volume 9 Nomor 1 Oktober .

Rakhmat, J. (1999). Tindakan kekersan terhadap anak dalam MIF.Baihaqi (Ed.)., Anak indonesia teraniayah. Bandung : Remaja Rosdakrya .

Rina , J., \& Rini , L. (2015). Kekerasa pada anak dalam keluarga . Proceeding Seminar Nasional , ISBN 978-602-71716-3-3.

Rusmil, K. (2004, juni 19 di rumah sakit ). Penganiayaan terhadap anak,. Makalah disampaikan pada seminar "penaganan korban kekersan pada wanita dan anak

Siti, M. (2017 ). Gambaran pendapatan orangtua dan kekersan pada anak dalam keluarga di gampong geulanggang teounguh kecamatan kota juang kabupaten bireuen. Psikodimensia, Volemen 16 Nomor 1 Januari-Juni hal 1-7.

Soetarso. (2004). Kekersan dalam Kluarga. Bahan Kuliah : Tidak dipubuhblikasikan .

Soetarso. (2004). Masalah ketelantaran anak. Bahan kuliah, tidak dipublikasikan .

Suharto, E. (1997 ). Pembangunan, Kebijakan Sosial, dan Pekerjaan Sosial. . Bandung : Lembaga Studi pPembangunan Sekolah Tinggi Kesejahteraan Sosial. .

Tribun, t. (2018, juli selasa ). 46 kasus kekerasan terhadap anak terjadi di bone 3 tahun terakhir . p. justang/tribunbone.com. 